DOI: 10.17951/lrp.2016.35.4.31

\author{
EWA BARNAŚ-BARAN
}

Uniwersytet Rzeszowski

\title{
NAUCZYCIELE SIEROT W KRAKOWSKIM TOWARZYSTWIE DOBROCZYNNOŚCI W LATACH 1817-1912
}

\begin{abstract}
Abstrakt: Celem artykułu było ukazanie pracy nauczycieli w szkole codziennej i szkole rzemiosł Towarzystwa Dobroczynności w Krakowie w latach 1817-1912. Uczący w nich nauczyciele stwarzali sierotom przebywającym w zakładzie Towarzystwa możliwość zdobycia elementarnej wiedzy oraz podstawowych umiejętności, które mogły ułatwić im znalezienie zatrudnienia po wyjściu spod opieki Towarzystwa. Funkcję wspierającą, jak również kontrolującą pracę nauczyciela pełniła powołana w 1874 r. Komisja Szkolna. W 1912 r. szkoła została zlikwidowana, sieroty przeniesiono do szkół miejskich w Krakowie. Zadaniem nauczyciela była pomoc w nauce dzieciom oraz sprawowanie wspólnie z Siostrami Miłosierdzia opieki nad sierotami w zakładzie Towarzystwa.
\end{abstract}

Słowa kluczowe: Krakowskie Towarzystwo Dobroczynności, Galicja, opieka, sieroty, dobroczynność

Na początku XIX wieku utworzono dwa największe towarzystwa dobroczynne na ziemiach polskich. W roku 1807 powstało Wileńskie Towarzystwo Dobroczynności (Wiadomości... 1819, s. 2; Markiewiczowa 1993, s. 117), w 1814 r. powołano Warszawskie Towarzystwo Dobroczynności (Historya... 1863, s. 1; Markiewiczowa 1990, s. 196). Jak podała Hanna Markiewiczowa, prasa warszawska, pisząc o powstaniu Warszawskiego Towarzystwa Dobroczynności, podkreślała, że czerpało ono wzorce $z$ funkcjonujących już instytucji w Hamburgu, Wiedniu, Monachium i Wilnie (Markiewiczowa 2002, s. 60). W deklarowanych celach podkreślano, że udzielana opieka będzie miała walory wychowawcze, gdyż poza schronieniem i wyżywieniem podopieczni towarzystw mieli również znaleźć pożyteczne zatrudnienie. Rok 1815 
był czasem utworzenia Lubelskiego Towarzystwa Dobroczynności, które zapowiadało objęcie opieką wszystkich potrzebujących i koncentrowało się na ograniczeniu żebractwa (Puszka 2013, s. 99). W 1816 r. powstało Krakowskie Towarzystwo Dobroczynności (Organizacya... 1817, s. 8), przejmując i łącząc fundusze kilkunastu szpitali krakowskich (Głębocki 1868, s. 23), ukierunkowując swoją działalność na walkę z żebractwem (Organizacya... 1817, s. 27) oraz pomoc tym ubogim, którzy $\mathrm{z}$ racji wieku i złego stanu zdrowia nie mogli zapracować na utrzymanie. Zapowiadano chęć wspierania ubogich, a także pomoc społeczeństwu w zwalczaniu ubóstwa, zwłaszcza rozpowszechnionego żebractwa. W Organizacyi i Ustawach Towarzystwa Dobroczynności wolnego Miasta Krakowa, pełniących rolę pierwszego statutu Towarzystwa, napisano: „Zasadą Towarzystwa iest zabronienie żebractwa iawnego w mieście, przedmieściach, na mieyscach publicznych, w Ulicach lub po domach; stała Opieka nad tą Massą Ubogich, przez zaspokojenie potrzeb i zatrudnienie pożyteczne" (Organizacya... 1817, s. 27). Utwierdzało ono mieszkańców Krakowa oraz całej Galicji w przekonaniu, że korzysta ono ze sprawdzonej formuły funkcjonowania, podając, że podobne towarzystwa powołano już w innych miastach (odwoływano się do przykładu Warszawy, Wilna, Lwowa, Mińska, Lublina oraz Poznania), oraz utrwalało przekonanie, że podoła ono zadaniu ograniczenia żebrania przez ubogich. Należy wspomnieć, że w kolejnych latach Towarzystwa Dobroczynności powstawały w innych miastach, w których lokalne społeczności łączyły siły w celu otoczenia opieką ubogich dorosłych i dzieci, a tym samym zahamowania wzrostu liczby żebraków (Encyklopedia... 1973, s. 1391).

Starców, kaleki oraz sieroty przyjęte pod opiekę Towarzystwa Dobroczynności w Krakowie (dalej: KTD) umieszczano w Domu Schronienia. Pierwotnie mieścił się w jednym ze skrzydeł zamku wawelskiego, po 1846 r. podopieczni zostali zmuszeni do opuszczenia zamku i przeniesienia się do klasztorów krakowskich. Sytuację zmienił zapis Ignacego Rotarskiego z 1853 r., w którym na potrzeby Towarzystwa przeznaczył dom przy ul. Koletek $12 \mathrm{w}$ dzielnicy Stradom. Na początku lat 80. XIX w. podjęto budowę nowego domu dla podopiecznych w ogrodzie przylegającym do ul. Koletek i w 1882 r. oddano go do użytku. W czasie I wojny światowej budynki częściowo zajęte zostały na potrzeby wojska. Należy wspomnieć, że po odzyskaniu niepodległości przez Polskę w $1918 \mathrm{r}$. KTD nadal funkcjonowało, a w latach 30. XX w. wybudowano kolejną część zakładu, do którego przyjmowano dorosłych zubożałych mieszkańców Krakowa. Część z nich przebywała tam, opłacając swój pobyt, w 1933 r. opuściły go ostatnie dziewczęta. Towarzystwo zostało zlikwidowane decyzją ówczesnych władz w $1951 \mathrm{r}$.

Towarzystwo Dobroczynności w Krakowie otaczało całkowitą opieką niedołężnych, wyczerpanych pracą ludzi starych, jak również kalekich, niezdolnych do pracy ubogich, którzy nie mieli wystarczających funduszy na własne utrzymanie, 
nie mogli również liczyć na pomoc rodziny. Po otwarciu przez Towarzystwo Domu Schronienia Ogólnego, w którym zamieszkali dorośli ubodzy, zaistniała potrzeba organizowania opieki również dla dzieci tych matek, które przebywały w zakładzie. W statucie Towarzystwa Dobroczynności z 1839 r. informowano, że „rozprzestrzeniło [ono - przyp. E.B.-B.] już zakres swych usiłowań, przyjmując pod opiekę dzieci, których rodzice dla ubóstwa lub kalectwa sami zostają w Domu Ogólnego schronienia" (Statut 1839, s. 3). Kryteria przyjęć od 1839 r. zawężono wiekiem i zamieszkaniem dzieci. Zdecydowano, że przyjmowane będą dzieci rodziców przebywających pod opieką KTD, które nie przekroczyły 10. roku życia oraz pochodziły z miasta i gminy Kraków. Kolejne zapisy w statutach ograniczały grupę przyjmowanych dzieci do tych, które należały do gminy miasta Krakowa i nie przekroczyły wieku 6-8 lat (Statut 1874, s. 3). Jeszcze w 1835 r. Towarzystwo przyjęło dzieci, których rodzice zostali zatrzymani i osadzeni w areszcie. W ten sposób rozpoczął się kolejny etap opieki nad tzw. sierotami rządowymi. Według zapisu w statucie z $1874 \mathrm{r}$. Wydział Spisu, podobnie jak w poprzednich latach, miał czuwać, aby po ukończeniu 12 lat dzieci nie pozostawały nadal w zakładzie Towarzystwa, ale były oddawane na służbę lub do pracy rzemieślniczej (Protokół z 9 grudnia 1892 r., k. 14; Statut 1874, s. 15). W statucie z 1885 r. podwyższono wiek dzieci, które opuszczały zakład Towarzystwa (Statut 1885, s. 17). Na naukę rzemiosła chłopcy mieli być oddawani po osiągnięciu 14. roku życia, dziewczęta powinny podejmować pracę służących po ukończonym 16. roku życia. Kolejny statut z 1901 r. nie zmieniał zapisu określającego warunki przyjęć dzieci (Statut 1901, k. 16).

Stała opieka polegała na zapewnieniu swym podopiecznym w Domu Schronienia Ogólnego (nazywanym następnie zakładem) podstawowych środków do życia, zaspokojeniu niezbędnych potrzeb: wyżywienia, ubrania, schronienia i pomocy lekarskiej. Stwarzano również możliwość zatrudnienia dla wszystkich tych pensjonariuszy, którym pozwalały na to warunki zdrowotne (Posiedzenie dnia 8 lutego 1817, k. 16). Opieka nad dziećmi koncentrowała się na tym, aby zostały wychowane na użytecznych członków społeczeństwa. W realizacji tak sformułowanego zadania miała być pomocna powołana w 1817 r. szkoła codzienna oraz utworzona w 1886 r. szkoła rzemiosł. Istotną rolę w kształtowaniu właściwej postawy moralnej i religijnej pełniły praktyki religijne oraz nauka chrześcijańska udzielana w każde święto (Posiedzenie dnia 8 lutego 1817, k. 12). Podopieczni Towarzystwa uczestniczyli również w nabożeństwach odbywających się w urządzonej w tym celu kaplicy (Posiedzenie XXXII dnia 9 listopada 1817, k. 62).

Analiza materiałów źródłowych, które zgromadzono w Archiwum Narodowym w Krakowie, pozwoliła na ukazanie funkcjonowania szkoły codziennej Krakowskiego Towarzystwa Dobroczynności w latach 1817-1912, obowiązujących nauczycieli programów nauczania, wytycznych do pracy formułowanych w instrukcjach 
oraz nazwisk tych, którzy nauczali sieroty. Znacznie mniej informacji, pomimo przeanalizowania szczegółowych rękopisów ksiąg zawierających protokoły posiedzeń organu zarządzającego Towarzystwem - Rady Ogólnej, ustalono na temat szkoły rzemiosł, którą powołano w latach 80 . XIX w. zgodnie z przyjętym ówcześnie kierunkiem nadania praktycznego wymiaru kształcenia dzieci. Należy również nadmienić, że w Towarzystwie w ramach przyjętego zwyczaju wygłaszania przemówień ukazujących działalność zasłużonych dla niego postaci, pisania i publikowania wspomnień, zamieszczania opisu ich działalności w Rocznikach Krakowskiego Towarzystwa Dobroczynności nauczycielom nie poświęcono wiele uwagi. W zachowanych archiwaliach bardzo bogaty zasób stanowią materiały dokumentujące finansową działalność Towarzystwa, znajdujemy bardzo dużą liczbę danych statystycznych ruchu ubogich w zakładzie, trudno było natomiast odszukać informacje o dydaktycznej i wychowawczej pracy jego członków bądź osób zatrudnianych. Należy odnotować, że prace nad zgromadzonymi w Archiwum Narodowym w Krakowie dokumentami działalności Towarzystwa trwają od dłuższego czasu i są kontynuowane. Dla poznania działalności Towarzystw Dobroczynności, w tym krakowskiego, oraz innych stowarzyszeń dobroczynnych na ziemiach polskich istotne były współczesne opracowania autorstwa Czesława Kępskiego (1990, 2003), Mariana Surdackiego (2002), Andrzeja Meissnera (2002), Anny Haratyk (2002), Moniki Piotrowskiej-Marchewy (2004), Marka Przeniosło $(2008,2010)$. W artykule przyjęto ramy chronologiczne, które odzwierciedlają czas, w którym zgodnie z materiałami archiwalnymi prowadzono zorganizowaną działalność edukacyjną, która ukonstytuowała się w postaci szkoły codziennej.

\section{SZKOŁA CODZIENNA}

W początkowym okresie działalności Towarzystwa Dobroczynności w Krakowie dla przyjętych sierot zorganizowano naukę pod opieką wytypowanych do tego starszych pensjonariuszy zakładu, pełniących funkcje nauczycieli. Zajęcia dla dzieci odbywały się w jednej z sal (Kilka słów... 1839, s. 18, 19). Rada Ogólna, która obawiała się, że nauczanie dzieci przez starców może nie przynieść oczekiwanych rezultatów, podjęła decyzję o założeniu od dnia 16.03 .1817 r. szkółki dla dzieci (Posiedzenie dnia 16.03.1817, k. 25). Józef Teodor Głębocki, członek i sekretarz KTD, tak opisał początki jej funkcjonowania: „Zaraz od początku zachodziła potrzeba przy domu schronienia dla starców, założyć dom sierot; urządzoną też od razu została bo dnia 16 marca 1817 r. szkółka, w której dzieci przy rodzicach w domu opieki będących, uczyły się religii, czytania, pisania, rachunków i robót ręcznych podług wieku i przeznaczenia, było ich na wstępie 24. Jeden z członków 
towarzystwa miał dozór nad nauczycielami i dozorczyniami wybranymi z pomiędzy ubogich mieszkających w tym domu, wskazując im sposób nauczania” (Głębocki 1852, s. 103). Dnia 27.04.1817 r. podjęto decyzję o zorganizowaniu „wydziału szkoły dla ubogich dzieci" (Posiedzenie dnia 27 kwietnia 1817, k. 32). Proponowano, aby wydziałem kierowali Ignacy i Jan Mieroszewscy. Ignacy Mieroszewski miał przygotować projekt, w którym zostałoby wyjaśnione, w jaki sposób Towarzystwo miało realizować zadanie „wychowania tych dzieci i usposobienia ich do pracy użyteczney bądź w Rzemiośle, bądź w jakimkolwiek kunszcie" (Posiedzenie dnia 27.04.1817, k. 32). W Pamiętniku Towarzystwa Dobroczynności Krakowskiego wydanym $z$ powodu obchodzonego $w$ d. 24 i 25 czerwca 1866 r. pięćdziesiąt-letniego Jubileuszu wskrzeszenia $w$ roku 1816 tegoż Towarzystwa zapisano, że pierwszy egzamin sierot odbył się $28.07 .1818 \mathrm{r}$. i od tej pory odbywały się one po zakończeniu każdego roku szkolnego (Pamiętnik... 1868, s. 78). W 1820 r. w zakładzie było 234 osoby, w tym 24 chłopców i 14 dziewcząt. Pierwszego stałego nauczyciela zatrudniono 18.06.1820 r., został nim Filip Skawinkiewicz z pensją $200 \mathrm{złp} \mathrm{rocznie} \mathrm{(Głęboc-}$ ki 1852 , s. 102, 103). W tym samym roku wydzielono w zakładzie oddzielne pomieszczenie, w którym dzieci pod opieką zawodowego nauczyciela, pobierały "początkowe nauki i ćwiczenia” (Rocznik... 1820, s. 21). Od 1.09 .1822 r. zajęcia prowadził Walenty Mrozowski, po roku pracy nauczyciela nastąpił okres trwający do grudnia 1833 r., w którym nauczaniem sierot zajmowali się pensjonariusze zakładu (Głębocki 1852, s. 127). Od 22.12.1833 r. w szkole zatrudniony był Wincenty Makowski, który w dniu 18.10.1840 r. zrezygnował z pracy w szkole Towarzystwa, ponieważ został mianowany nauczycielem szkoły wydziałowej w dzielnicy Kazimierz w Krakowie (Głębocki 1852, s. 135). Po Wincentym Makowskim nauczycielem szkoły codziennej w 1840 r. z pensją 500 fr rocznie został Jacek Majewski. Egzaminy potwierdzały, że postępy dzieci były zadowalające, postanowiono w związku z tym podnieść pensję nauczyciela od 24.07.1842 r. o $300 \mathrm{fr}$ (Sesja dnia 15.06.1845, k. 21).

Na początku lat 30. XIX w. dokonano reorganizacji szkoły pod kierunkiem Stanisława Pogonowskiego, nauczyciela Liceum św. Anny w Krakowie (Programma..., s. 4), dostosowując jej program nauczania do programów szkół parafialnych. W 1837 r. Towarzystwo miało 395 podopiecznych, z tego 93 dzieci. Chłopców było 50, natomiast dziewcząt 43 . W 1839 r. przeprowadzono remont sali przeznaczonej do nauki, rozdzielono uczących się chłopców i dziewczęta. Nauczycielowi podniesiono pensję do 600 złp (Głębocki 1852, s. 133). W szkole obowiązywał program nauczania, który obejmował naukę religii i moralności, czytanie i pisanie w języku polskim, arytmetykę, geografię, naukę języka niemieckiego. Wprowadzono język niemiecki dla tych uczniów, którzy w dobrym stopniu opanowali język polski (Rocznik... 1839, s. 23). Dzieci zapoznawano z elementarnymi 
zasadami nauki obyczajowej, moralności oraz rysunku linearnego. Naukę religii i moralności prowadzono na 2 kursach - dla początkujących i zaawansowanych. Skutkiem epidemii cholery w Krakowie był dalszy wzrost liczby podopiecznych w zakładzie. W 1840 r. w zakładzie było 469 osób, 50 chłopców i 37 dziewcząt.

Po dalszych kilku latach pracy 12.06 .1858 r. nauczyciel szkoły sierot Jacek Majewski zmarł (Posiedzenie zwyczajne w dniu 13.06 .1858 odbyte, k. 398). Uznając jego zasługi w pracy, Rada Ogólna przez 18 lat udzielała jego rodzinie zasiłek na pogrzeb w kwocie 100 złp i przyjęła podanie wdowy z trójką dzieci z prośbą o możliwość dalszego mieszkania w zakładzie. Jak wynika z protokołów posiedzeń Rady Ogólnej, pracę w szkole sierot podjął w 1858 r. kolejny nauczyciel - Antoni Maliszewski, który przed objęciem posady w szkole Towarzystwa uczył w szkole parafialnej w Morawicy (Posiedzenie zwyczajne w dniu 6.03 .1859 odbyte, k. 511). W protokole posiedzeń Rady Ogólnej z 9.12.1859 r. zapisano, że nauczyciel miał obowiązek mieszkać w budynku razem z dziećmi, a mógł nim zostać jedynie „mąż w zawodzie Nauczycielstwa zasłużony" (Posiedzenie zwyczajne z 9.12.1859, k. 645), czyli osoba mająca doświadczenie i dobrą ocenę dotychczasowej pracy. W 1859 r. odnotowano, że dziewczęta pod nadzorem ich opiekunki - ochmistrzyni - uczono zarówno szycia, jak i wszelkiego rodzaju czynności kobiecych, zaś chłopców „uznano za potrzebę zaprowadzić na naukę rzemiosł szewskiego i krawieckiego" (Posiedzenie zwyczajne z 9.12.1859, k. 646). Nauczycielem w szkole sierot od lat 70. XIX w. do jej zlikwidowania w 1912 r. był Antoni Mardeusz, który w latach 60. XIX w. był zatrudniony w Gimnazjum św. Anny w Krakowie (Rocznik... 1877, s. 87; Rocznik... 1912, s. 7). W latach 50. i 60. XIX w. liczba dzieci w zakładzie była utrzymana na podobnym poziomie, tj. 20-26 chłopców i 16-20 dziewcząt. W 1860 r. na 244 podopiecznych zakładu było razem 46 dzieci. $Z$ analizy danych statystycznych zamieszczanych w Rocznikach Krakowskiego Towarzystwa Dobroczynności wynika, że do początku XX w. liczba dzieci przyjętych pod opiekę oraz dorosłych była zbliżona. Zmniejszyła się w 1902 r., kiedy wynosiła 177 pensjonariuszy zakładu, z tego 16 chłopców i 20 dziewcząt (Rocznik... 1912, s. 13).

Kolejny etap zmian w funkcjonowaniu szkoły codziennej nastąpił w latach 70. XIX w. W 1874 r. Rada Ogólna zarządzająca Towarzystwem powołała Komisję Szkolną, która pełniła funkcję wewnętrznego organu wspierającego i kontrolującego działalność szkoły, nauczyciela i ochmistrzyń. W Statucie Towarzystwa Dobroczynności z 1874 r. zapisano, że nadzór Komisji miał być realizowany w zakresie dydaktycznym i pedagogicznym. W skład Komisji Szkolnej od 1.03.1874 r. wchodzili Leon Cyfrowicz, członek Rady Ogólnej, sekretarz Uniwersytetu Jagiellońskiego, redaktor krakowskiego „Czasu”, Julian Maciołowski, członek Towarzystwa Dobroczynności i dyrektor szkoły ludowej miejskiej, Marceli Chmielewski, dyrektor szkoły żeńskiej przy klasztorze św. Andrzeja (Statut 1874, s. 15). Instrukcja dla 
Komisji, przygotowana przez L. Cyfrowicza, została uchwalona przez Radę Główną Towarzystwa Dobroczynności na posiedzeniu 1 i 8.11.1874 r. (Instrukcya dla Komisyi Szkolnej 1881, s. 113). Członkowie Komisji rozstrzygali również w kwestiach dyscyplinarnych, zwłaszcza w sytuacji kiedy środki wychowawcze stosowane przez nauczyciela nie przynosiły oczekiwanego efektu. Bez zgody jej członków uczeń nie mógł być karany fizycznie. Na początku roku szkolnego 1874/1875 Komisja Szkolna rozpoczęła reorganizację szkoły zakładowej. W dniu 18.10.1874 r. przedstawiła na posiedzeniu Rady Ogólnej projekt instrukcji dla nauczyciela oraz plan nauczania w szkole, zajęto się również doposażeniem istniejących sal dla dzieci w potrzebne do nauki wyposażenie. W tym czasie materiały dydaktyczne szkoły wzbogacił m.in. Józef Patelski, który ofiarował ponad sto dwadzieścia różnych okazów nasion, zbóż itp., jeden z członków Komisji Szkolnej przekazał bogaty zbiór minerałów. Ponadto odnowiono i pomalowano salę szkolną, koszty tych prac pokrył Józef Pochwalski (Rocznik... 1875, s. 7). Zakupiono nowe, dla wszystkich dzieci jednakowe, ławki szkolne tzw. systemu ołomunieckiego, które były uznane za najlepsze.

Instrukcya dla nauczyciela szkoły sierót w Krakowskim Towarzystwie Dobroczynności przyjęta została uchwałą Rady Ogólnej na posiedzeniu 18.10.1874 r., ostatecznie zatwierdzono ją 5.12.1880 r. (Instrukcya dla nauczyciela szkoły sierót 1875, s. 6). Nauczyciel nie mógł podejmować dodatkowego zatrudnienia, praca na rzecz szkoły obejmowała nadzór nad dziećmi i młodzieżą w czasie zajęć oraz w godzinach pozalekcyjnych. Osoby powołane do opieki i kształcenia dzieci (nauczyciel, kapelan, ochmistrzynie) mieli za zadanie utrzymywać dyscyplinę, zachęcać do pracy, wdrażać normy moralnego postępowania. Nauczyciel miał starać się utrzymywać jak największą karność wśród dzieci, odwoływać się do ojcowskiej zachęty do cnoty i pracy, a sieroty miał umoralniać za pomocą środków dozwolonych w szkołach. W Instrukcji pisano, że ani jemu, ani katechecie, ani ochmistrzyniom nie wolno „pod osobistą odpowiedzialnością używać kary cielesnej” (Instrukcya dla nauczyciela szkoły sierót 1875, s. 6). Do pomocy nauczyciela Komisja wyznaczyła ochmistrzynie chłopców i ochmistrzynie dziewcząt.

Praca z dziećmi nauczyciela i ochmistrzyń była realizowana na podstawie całodziennego planu dnia, w szkole Towarzystwa wytyczną do pracy był plan nauczania, nauczyciel był zobowiązany przygotowywać tygodniowy program pracy (Instrukcya dla nauczyciela szkoły sierót 1875, s. 6). Pobudkę przewidywano na godzinę 6 rano, po toalecie porannej, uporządkowaniu sypialni dzieci odmawiały modlitwę poranną w sali lub kaplicy i spożywały śniadanie. Zajęcia szkolne rozpoczynały się o godzinie 8 i trwały do 11, obiad wyznaczono na godzinę 12. Pomiędzy zajęciami szkolnymi a posiłkiem przewidywano godzinną rekreację dzieci na świeżym powietrzu, ćwiczenia gimnastyczne, gry, zabawy, spacer, odbywające się pod dozorem ochmistrzyń. Po obiedzie następował aktywny wypoczynek oraz przygotowywanie 
się do zajęć popołudniowych, które rozpoczynały się o godzinie 14, kolację spożywano o 18, po odmówieniu modlitwy wieczornej dzieci udawały się o godzinie 21 na wypoczynek nocny. W czasie wolnym od zajęć szkolnych wychowankowie uczyli się szycia, wyplatania, kroju. W dni wolne lub świąteczne wychodziły pod opieką ochmistrzyń na spacery za miasto, w trakcie których „praktycznie zaznajamiano z różnemi tworami przyrody” (Instrukcya dla nauczyciela szkoły sierót 1875, s. 5). Nauczyciel wraz z kapelanem i ochmistrzyniami byli zobowiązani do organizowania dla dzieci majówki. Projekty, pomysły zabawy mógł konsultować z prowizorem, po odbytej majówce składał sprawozdanie finansowe Wydziałowi Gospodarczemu.

Komisja Szkolna zorganizowała szkołę dla sierot jako prywatną, jednoklasową z trzema oddziałami. Pełna jej nazwa brzmiała: „Jednoklasowa, nierozdzielna szkoła ludowa z całodzienną nauką przy Towarzystwie Dobroczynnym w Krakowie". Plan nauczania obejmował religię, język polski, rachunki, wiadomości z przyrody, naukę o ziemi i jej dziejach, pisanie, rysunki i naukę form geometrycznych, śpiew i gimnastykę. Uczniów zgrupowano w trzech oddziałach: „oddział I - pierwszy rok wieku obowiązującego do nauki szkolnej, oddział II - drugi, trzeci rok wieku obowiązującego do nauki szkolnej, oddział III - czwarty, piąty i szósty rok wieku obowiązującego do nauki szkolnej”. Wymiar godzin lekcyjnych dla poszczególnych oddziałów był zróżnicowany. W oddziale I liczba godzin tygodniowo wynosiła dziewiętnaście, w II - dwadzieścia pięć, w III - dwadzieścia osiem. W szkole był zatrudniony jeden nauczyciel, dlatego podczas zajęć głośnych w jednym oddziale w dwóch pozostałych obowiązywała cisza. Nauka szkolna odbywała się codziennie rano od godziny 8 do 11 i po południu od 14 do $16 \mathrm{z}$ wyjątkiem niedziel i świąt oraz środy i soboty po południu. Moralnym obowiązkiem nauczyciela było przekazanie dzieciom wiedzy, którą mogły wykorzystać w życiu. Zdobyte umiejętności miały zwiększyć szansę na znalezienie pracy zarobkowej po opuszczeniu zakładu Towarzystwa przez sieroty.

Ćwiczenia gimnastyczne wprowadzono w $1883 \mathrm{r}$., realizowano je na podstawie programu Gimnastyka dla szkół ludowych, zatwierdzonego przez Radę Ogólną. Na utrzymanie zajęć gimnastycznych przeznaczono część pieniędzy pochodzących $\mathrm{z}$ majówek, a także dochód z funduszu $100 \mathrm{złp} \mathrm{ofiarowanego} \mathrm{przez} \mathrm{rodzinę} \mathrm{Patel-}$ skich. Po uposażeniu szkoły w odpowiedni sprzęt zakupiony 5.05.1889 r. od Adolfa Meissnera za sumę 40 złp dzieci odbywały zajęcia gimnastyczne od lipca $1889 \mathrm{r}$. pod kierunkiem nauczyciela Gędłka, który był zatrudniony również przez Towarzystwo „Sokół” (Rocznik 1889, s. 51; „Nowa Reforma” 1889, s. 3). Na zakończenie roku szkolnego 1888/1889 odbył się popis umiejętności gimnastycznych uczniów przygotowujących się pod kierunkiem wymienionego nauczyciela (Bąk 1975, s. 112). 
Na zajęciach przeznaczonych na tzw. roboty dziewczęta uczyły się szydełkowania, robienia na drutach, cerowania, szycia, sporządzania wykrojów itp. Przedmioty i wytwory z zajęć praktycznych znajdowały zastosowanie w Domu Schronienia, a niejednokrotnie przynosiły zyski finansowe pochodzące ze sprzedaży wykonanych przez uczennice materiałów.

Członkowie Towarzystwa oraz Komisji Szkolnej w latach 80. XIX w. nadal wzbogacali szkołę w pomoce dydaktyczne (L. Cyfrowicz ofiarował śpiewniki, zaprenumerowano czasopismo „Szkoła”) (Protokół z 18.06.1882, k. 705), a także pozyskiwali osoby, które mogły wspomóc szkołę w realizacji planu nauczania (Protokół z 22.04.1883, k. 799), m.in. organistę do nauki śpiewu. Obowiązkiem nauczyciela było zwracanie uwagi na poszczególnych lekcjach na wiadomości potrzebne do prowadzenia gospodarstwa domowego. Wychowanków uczono nie tylko sposobów prowadzenia tegoż gospodarstwa, lecz także odpowiedniej organizacji pracy, umiejętności podziału zajęć. Praktyczne przygotowanie zwiększało szansę sierot na znalezienie zatrudnienia. Na posiedzeniu Rady Ogólnej 5.02.1882 r. poinformowano, że Magistrat miasta Krakowa miał przesyłać informacje o zgłaszających się osobach, które wyrażały chęć przyjmowania dzieci po ukończonym 12. roku życia do służby lub rzemiosła (Protokół z 5.02.1882, k. 671). W 1883 r. na przewodniczącego Komisji Szkolnej zaproszono wiceprezesa Towarzystwa dra Jana Hajdukiewicza w związku z rezygnacją dotychczasowych członków (Protokół z 23.12.1883, k. 879). Od 1885 r. jeden z jej członków musiał należeć do Wydziału Spisu (Protokół z 20.02.1885, k. 1039). W 1885 r. kolejny przewodniczący Komisji Szkolnej dr Maurycy Fierich ofiarował książki na nagrody, kapelan 36 obrazków i 2 książki (Protokół z 17.05.1885, k. 1086). W kwietniu 1886 r. po zrzeczeniu M. Fiericha z przewodniczenia i udziału w pracach Komisji, na członka zaproszono Witalisa Szpakowskiego, przewodniczącym wybrano Leona Cyfrowicza (Protokół z 4.04.1886, k. 1177). Jak wynika z protokołów Rady Ogólnej, w kolejnych latach funkcjonowania szkoły starano się wzbogacać wyposażenie szkoły (w 1889 r. prezes KTD podarował obraz Kościuszko pod Racławicami, który był oprawiony w ramy i oszklony) (Protokół z 5.05.1889, k. 1605), usuwano zepsute sprzęty bądź naprawiano niektóre własnymi siłami, zajmowali się tym od $1886 \mathrm{r}$. uczniowie powołanej w zakładzie szkoły rzemiosł. Na wniosek nauczyciela przedstawiony Radzie Ogólnej malowano tablicę szkolną, reperowano popsute ławki. Nauczyciel, będąc gospodarzem szkoły, dbał również o to, by praca jego i uczniów była dostrzegana przez członków KTD oraz mieszkańców Krakowa. Na uroczyste zakończenia roku szkolnego byli zapraszani członkowie Rady Ogólnej oraz Damy KTD (Protokół z 5.07.1888, k. 1489). W roku szkolnym 1889/1890 uroczyste zakończenie zaplanowano na 25 czerwca i miało się odbyć pod przewodnictwem Teodora Baranowskiego jako delegata Rady Szkolnej Krajowej. Rada Ogólna na 
wniosek L. Cyfrowicza zaprosiła wszystkich członków oraz Komitet Dam do udziału w uroczystości (Protokół z 8 czerwca 1890, k. 1809). W latach 90. XIX w. nadal odbywały się uroczyste zakończenia roku szkolnego, po zakończonych zajęciach w danym roku szkolnym nauczyciel przygotowywał na posiedzenie Rady Ogólnej wykaz sierot, które za wysokie wyniki w nauce miały być nagradzane (Protokół z 12.06.1892, k. 2141; Protokół z 7.02.1892, k. 2073; Posiedzenie z 3.06.1912, k. 82). Członkowie Rady byli informowani również przez niego o wydatkach szkolnych (Protokół z 6.10.1913, k. 107). Po rozwiązaniu szkoły Towarzystwa z jego funduszów nadal przeznaczano środki na potrzeby szkolne dzieci.

$\mathrm{Z}$ analizy materiałów archiwalnych wynika, że funkcjonowanie szkoły codziennej Towarzystwa na początku XX w. się pogarszało. Dnia 23.05.1904 r. zmarł L. Cyfrowicz, który przyczynił się do wielu pozytywnych zmian w systemie opieki i kształcenia sierot KTD.

Z protokołu z 6.11.1911 r. dowiadujemy się, że planowane przygotowanie sierot do przyszłej pracy zarobkowej nie było realizowane na początku XX w. w stopniu odpowiadającym oczekiwaniom osób, które miały je zatrudniać. Zarzuty formułowano zwłaszcza wobec dziewcząt, które ukończyły 16 lat (Posiedzenie z 6.11.1911, k. 68). Z przygotowanego przez Oddział Dam referatu, który odczytał na kolejnym posiedzeniu przewodniczący Komisji Szkolnej ks. dr F. Świderski, wynikało, że zwrócono w nim uwagę na zbyt mały zakres praktycznego przygotowania podopiecznych do służby i dalszej pracy, ale nie zamieszczono tam propozycji rozwiązania tego problemu (Posiedzenie z 4.12., k. 71). Kolejny rok zamykał niemalże stuletnią tradycję kształcenia sierot przez KTD w prowadzonej przez to Towarzystwo szkole. Był to również czas, kiedy rozważano i ostatecznie podjęto decyzję o jej zamknięciu. Pogarszająca się sytuacja finansowa Towarzystwa przed wybuchem I wojny światowej, brak nowych pomysłów i osób wspomagających prawidłowe funkcjonowanie szkoły (Encyklopedia Krakowa 2000, s. 132) przyczyniły się do podjęcia przez Radę Ogólną decyzji o rozwiązaniu szkoły w zakładzie (Rocznik... 1912, s. 4). Dnia 9.05 .1912 r. ks. dr F. Świderski wnioskował, aby sieroty z zakładu podejmujące naukę w szkołach miejskich udawały się tam pod opieką Sióstr Miłosierdzia, które od 1904 r. przejęły opiekę w zakładzie nad sierotami, a także nauczyciela Antoniego Mardeusza. Siostry Miłosierdzia miały odprowadzać i przyprowadzać dziewczęta do zakładu, natomiast nauczyciel miał towarzyszyć chłopcom. Ponadto zadaniem nauczyciela była pomoc podopiecznym w nauce i przygotowywanie ich do kolejnej klasy. Rada Ogólna przyjęła wniosek i od 1.09.1912 r. miały uczęszczać do szkół miejskich (Protokół z 9.05.1912, k. 80). W protokole posiedzeń Rady Ogólnej z 2.09.1912 r. zapisano: „Szkoła sierot jaka się w zakładzie znajduje zostaje zwiniętą a w myśl Uchwały Rady Ogólnej z dnia 6 maja b.r. będą dzieci do miejskich szkół wysyłane i w tym celu umieszczone w szkole 
imienia Cesarza Franciszka Józefa 17 chłopców a w szkole imieniem Konarskiego 17 dziewcząt o czem Radę Szkolną powiadomiono" (Protokół z 2.09.1912, k. 84; Rocznik... 1912, s. 5).

\section{SZKOŁA RZEMIOSŁ}

Poza szkołą codzienną powołano przy Towarzystwie Dobroczynności tzw. szkołę rzemiosł. Jej prototypem była sala rzemiosł, która powstała dzięki staraniom Leona Cyfrowicza, przewodniczącego Komisji Szkolnej (Rocznik... 1886, s. 21, 27). Jej istnienie było uwarunkowane koniecznością nadania praktycznego kierunku nauczaniu. Problemy lokalowe opóźniały rozpoczęcie działalności szkoły rzemiosł. W 1882 r. w związku z rozbudową zakładu i powiększeniem powierzchni dla sierot ówczesna Komisja Szkolna przedstawiła projekt „nauki rzemiosł dla chłopców, a praktycznych robót kobiecych dla dziewcząt" (Rocznik... 1886, s. 21, 27). W 1885 r. zaplanowano wyjazd L. Cyfrowicza do Warszawy w celu zwiedzenia tamtejszych zakładów dobroczynnych, a przede wszystkim urządzonych przy nich warsztatów do różnych rzemiosł (Rocznik... 1886, s. 23). W związku z tym że w planie budowy nowych pomieszczeń dla podopiecznych Towarzystwa uwzględniono również salę rzemiosł, na posiedzeniu Rady Ogólnej 4.04.1886 r. ustalono, że „obok istniejącej szkoły w Towarzystwie Dobroczynności ma być zaprowadzony oddział osobny, do którego przechodzić będą dzieci, które ukończyły tę szkołę i 12 rok życia. W tym osobnym oddziale chłopcy od lat dwunastu przyuczać się będą rzemiosł i uczyć się będą tych przedmiotów, które z rzemiosłem moją styczność, przede wszystkim zaś rysunków odpowiednich, dziewczęta zaś również od lat dwunastu przyuczać się będą robót kobiecych praktycznych i uczyć się będą przedmiotów do nich zastosowanych [...]" (Rocznik... 1886, s. 23).

Rada Ogólna poleciła Komisji Szkolnej wprowadzenie w szkole rzemiosł nauki szewstwa, krawiectwa i stolarstwa dla chłopców; nauczycieli tych zawodów Komisja była zobowiązana znaleźć wśród ubogich starców, którzy byli pod opieką Towarzystwa i posiadali wymagane kwalifikacje. Starcom uczącym chłopców wypłacano dziesięć centów dziennie w formie dodatku do strawnego. Na oddziale dziewcząt wprowadzono naukę gotowania, prania, prasowania, szycia, naukę wykrojów. Wkrótce okazało się, że zbyt mało sierot miało ukończone 12 lat i szkołę codzienną. W związku z tym Komisja Szkolna wybrała z III oddziału szkoły kilku chłopców dobrze fizycznie rozwiniętych, po czym rozpoczęto z nimi naukę, poświęcając jej początkowo tylko dwie godziny w tygodniu. W szkole rzemiosł przygotowywano dziewięciu chłopców: trzech do nauki szewstwa, trzech do krawiectwa i trzech do stolarstwa. Nauką zajęli się trzej majstrzy, z których jeden przebywał w Domu 
Schronienia. Warsztaty do nauki zostały uposażone przez bogatych rzemieślników krakowskich. Na oddziale stolarskim uczniowie poznawali narzędzia, osadzali je, robili stołki, ramy, skrzynie, trumny, naprawiali narzędzia i w niedługim czasie po otwarciu szkoły zrobili parę ławek do ogrodu, prosty stół z szufladą, skrzynię na ubrania i sześć klęczników. Nacisk kładziono na umiejętność cięcia i heblowania drzewa (Sprawozdanie Komisji Szkolnej 1889, s. 19-24). Na oddziale szewskim chłopcy osadzali szydła, kręcili dratwy, uczyli się nazw narzędzi, zszywali dratwą rzemyki, przyszywali przyszczypki do butów, reperowali obuwie, żelowali je, a nawet robili nowe buty. Kandydaci na krawców uczyli się ściegów, szyli bluzki dla chłopców, spodnie, marynarki, surduciki. Młodsi chłopcy w salach, w których mieszkali, szyli ręcznie prześcieradła, poszewki, kalesony, chustki do nosa, fartuchy. Dziewczęta podzielono na trzy grupy. Pierwsza z nich uczyła się szycia igłą i wykańczania pończoch; druga - robót szydełkowych, cerowania, łatania; trzecia - szycia bielizny, robót na kanwie, haftowania. Prac tych uczyła wychowanki sama ochmistrzyni. Ponadto dziewczęta szydełkowały, tkały na krosnach, haftowały na tamborku, prały kapy na łóżka, chustki, fartuszki, pończochy, kołnierzyki, pomagały w kuchni (Sprawozdanie Komisji Szkolnej 1889, s. 19-24). Starano się sprzedawać wytwory pracy wychowanków szkoły rzemiosł, a pozyskane kwoty były przekazywane na rzecz podopiecznych.

Opiekę nad funkcjonowaniem szkoły rzemiosł w latach 80. i 90. XIX w. nadal sprawował L. Cyfrowicz. W protokołach posiedzeń z 9.12.1889 r. oraz 9.12.1892 r. zapisano, że szkoła rzemiosł rozwijała się pomyślnie (Protokół z 9.12.1889, k. 48; Protokół z 9.12.1892, k. 92), aczkolwiek możemy również przeczytać o tym, że Rada Ogólna kierowała apele do członków Towarzystwa z prośbą o większe zainteresowanie się losem szkoły. Jedna z planowanych zmian dotyczyła takiego funkcjonowania kuchni, aby dziewczęta pod kierunkiem ochmistrzyni mogły uczyć się tam zajęć kuchennych. W analizowanych materiałach źródłowych nie znaleziono informacji o rozwiązaniu szkoły rzemiosł, ale należy przypuszczać, że decyzja o zlikwidowaniu szkoły codziennej dotyczyła również i tej formy kształcenia. W analizowanych protokołach posiedzeń Rady Ogólnej z lat 1918-1940 nie zamieszczono wzmianki o szkole rzemiosł.

Krakowskie Towarzystwo Dobroczynności utworzone w 1816 r. należało do grona Towarzystw Dobroczynności powstających w pierwszej połowie XIX w., które wychodziły naprzeciw społecznym oczekiwaniom ograniczenia zjawiska nędzy, jak również związanego z nim żebrania osób niemających środków na własne utrzymanie. Zaplanowana opieka nad starcami i kalekami była konsekwentnie realizowana, starano się zabezpieczać im schronienie, wyżywienie, ubranie, pomoc lekarską oraz zgodnie z ówczesnymi tendencjami dbano, by podopieczni byli zajęci pożytecznymi czynnościami. Wielokrotnie członkowie Rady Ogólnej podkreślali, 
że wiek i stan zdrowia starców mieszkających w zakładzie Towarzystwa nie pozwalał im na wykonywanie ciężkiej pracy, zatrudniano ich w związku z tym do darcia pierza, robienia bandaży oraz innych lekkich prac. Należy podkreślić, że Towarzystwo zorganizowało również opiekę nad dziećmi, sierotami tych rodziców, którzy przebywali w zakładzie. Jak podkreślono w statucie z 1839 r., była to odpowiedź na zaistniałą sytuację oraz dowód na rozwój Towarzystwa. Dla dzieci w zakładzie zorganizowano naukę, która początkowo była realizowana siłami starców przebywających w zakładzie, od 1820 r. zatrudniono nauczyciela. Przez niemal stuletni okres funkcjonowania szkoły codziennej, zwanej również zakładową, nauczaniem zajmowali się mężczyźni, a kobiety, tj. ochmistrzynie, pracowały z dziewczętami, uposażając je w podstawowe umiejętności, jak szycie, haftowanie, cerowanie, prowadzenie gospodarstwa. Opieką i wychowaniem chłopców zajmowały się ochmistrzynie chłopców. Staraniem członków powołanej w 1874 r. Komisji Szkolnej zorganizowano również szkołę rzemiosł w 1886 r., przeznaczoną dla starszych sierot. Naukę prowadzili w niej majstrowie, którzy przebywali w zakładzie, oraz wynajęci rzemieślnicy. Jak już wspomniano, od nauczyciela sierot KTD oczekiwano sumiennego wypełniania obowiązków, od lat 70. XIX również zobowiązywano go do nieprzyjmowania żadnych dodatkowych zajęć. Z próśb, które wnosili nauczyciele do Rady Ogólnej o zapomogę lub podwyżkę pensji, można wnioskować, że nie zawsze zaspokajała ona potrzeby nauczyciela i rodziny, którą posiadał. Wykonana praca w szkole była oceniana przez członków Rady Ogólnej i zaproszonych gości podczas egzaminów kończących rok szkolny, a nauczyciel i uczniowie mieli szansę na nagrodę - pochwalę lub niewysoką kwotę pieniędzy. W analizowanych materiałach archiwalnych nie znaleziono jednakże wiele informacji poświęconych nauczycielom, natomiast doceniano w nich i eksponowano dobroczynne gesty osób zamożnych, które wspierały Towarzystwo finansowo.

\section{LITERATURA}

Bąk J., 1975, Opieka społeczna nad sierotami w Krakowskiem Towarzystwie Dobroczynności w latach 1816-1916. „Rocznik Krakowski” XLVI, 99-112.

Dziewiąte posiedzenie Rady Ogólnej dnia 6 listopada 1911. W: Protokół z posiedzeń Rady Ogólnej Towarzystwa Dobroczynności począwszy od Stycznia 1909, sygn. TD 319, rękopis (dalej: rękop.).

Encyklopedia katolicka, 1973, F. Gryglewicz, R. Łukaszyk, Z. Sułowski (red.), t. 1. Lublin, Wydawnictwo Naukowe KUL.

Encyklopedia Krakowa, 2000, A.H. Stachowski (red. prowadz.). Warszawa-Kraków, Wydawnictwo PWN. 
Głębocki J.T., 1852, Zakłady ku ulżeniu cierpieniom bliźnich obecnie w Krakowie istniejace. Z krótka wzmianką o dawniejszych, a dziśnie istniejących instytucyach tego rodzaju. Kraków.

Głębocki J.T., 1868, Dawniejsze zakłady dobroczynne, tak zwane Szpitale Krakowskie. W: Pamiętnik Towarzystwa Dobroczynności Krakowskiego wydany z powodu obchodzonego wd. 24 i 25 czerwca 1866 r. pięćdziesiąt-letniego Jubileuszu wskrzeszenia w roku 1816 tegoż Towarzystwa. Kraków.

Haratyk A., 2002, Rozwój opieki nad dziećmi i młodzieża w Galicji doby autonomicznej. Wrocław, Instytut Pedagogiki Uniwersytetu Wrocławskiego.

Historya Warszawskiego Towarzystwa Dobroczynności od 1814 do 1852 r., 1863. W: Kalendarz wydany przez Warszawskie Towarzystwo Dobroczynności za rok 1863. Warszawa.

Instrukcya dla Komisyi Szkolnej w Krakowskiem Towarzystwie Dobroczynności, 1874. Kraków.

Instrukcya dla nauczyciela szkoły sierót w Krakowskim Towarzystwie Dobroczynności, 1875. Kraków.

Kępski C., 1990, Lubelskie Towarzystwo Dobroczynności (1815-1952). Lublin, Wydawnictwo UMCS.

Kępski C., 2003, Idea miłosierdzia a dobroczynność i opieka. Lublin, Wydawnictwo UMCS.

Kilka słów o dobroczynnych i miłosiernych zakładach wraz z treścią historyczna założenia szkoły poczatkowej dla sierot pod opieka Towarzystwa Dobroczynności W.M. Krakowa zostających, 1839. W: Rocznik Towarzystwa Dobroczynności Wolnego Miasta Krakowa z roku 1838. Kraków.

Markiewiczowa H., 1990, Działalność wychowawczo-opiekuńcza Warszawskiego Towarzystwa Dobroczynności w latach 1814-1914. „Przegląd Historyczno-Oświatowy" 33 (2), 196-206.

Markiewiczowa H., 1993, Działalność Wileńskiego Towarzystwa Dobroczynności w początkach XIX stulecia. „Kultura i Edukacja”, 117-124.

Markiewiczowa H., 2002, Działalność opiekuńczo-wychowawcza Warszawskiego Towarzystwa Dobroczynności 1814-1914. Warszawa, Wydawnictwo Akademii Pedagogiki Specjalnej.

Meissner A. (red.), 2002, Galicja i jej dziedzictwo. T. 16: Opieka nad dzieckiem $w$ Galicji. Rzeszów, Wydawnictwo URz.

„Nowa Reforma” 28.06.1889, 146.

Organizacya i Ustawy Towarzystwa Dobroczynności wolnego Miasta Krakowa., 1817, Kraków. 
Pamiętnik Towarzystwa Dobroczynności Krakowskiego wydanym z powodu obchodzonego wd. 24 i 25 czerwca 1866 r. pięćdziesiąt-letniego Jubileuszu wskrzeszenia w roku 1816 tegoż Towarzystwa., 1868, Kraków, Wydawnictwo Adam Marszałek.

Piotrowska-Marchewa M., 2004, Nędzarze i filantropi. Problem ubóstwa w polskiej opinii publicznej w latach 1815-1863. Toruń, Wydawnictwo Adam Marszałek.

Posiedzenie dnia 16.03.1817. W: Protokół pierwszy posiedzeń Towarzystwa Dobroczynności w Krakowie od 1816 do 1827, sygn. TD 7, rękop.

Posiedzenie dnia 27.04.1817. W: Protokół pierwszy posiedzeń Towarzystwa Dobroczynności w Krakowie od 1816 do 1827, sygn. TD 7, rękop.

Posiedzenie dnia 8.02.1817. W: Protokół pierwszy posiedzeń Towarzystwa Dobroczynności w Krakowie od 1816 do 1827, sygn. TD 7, rękop.

Posiedzenie Rady Ogólnej z dnia 3.06.1912. W: Protokół z posiedzeń Rady Ogólnej Towarzystwa Dobroczynności począwszy od Stycznia 1909, sygn. TD 319, rękop.

Posiedzenie Rady Ogólnej z dnia 9 maja 1912. W: Protokół z posiedzeń Rady Ogólnej Towarzystwa Dobroczynności począwszy od Stycznia 1909, sygn. TD 319, rękop.

Posiedzenie XXXII dnia 9.11.1817. W: Protokół pierwszy posiedzeń Towarzystwa Dobroczynności w Krakowie od 1816 do 1827, sygn. TD 7, rękop.

Posiedzenie zwyczajne Rady Ogólnej w dniu 13.06.1858 odbyte. W: Piąty tom Protokołu obrad Rady Ogólnej Towarzystwa Dobroczynności w Krakowie od roku 1855-1860, sygn. TD 6, rękop.

Posiedzenie zwyczajne Rady Ogólnej w dniu 6.03.1859 odbyte. W: Piaty tom Protokołu obrad Rady Ogólnej Towarzystwa Dobroczynności w Krakowie od roku 1855-1860, sygn. TD 6, rękop.

Posiedzenie zwyczajne Rady Ogólnej z 9.12.1859. W: Piąty tom Protokołu obrad Rady Ogólnej Towarzystwa Dobroczynności w Krakowie od roku 1855-1860, sygn. TD 6, rękop.

Programma popisów publicznych uczniów Liceum Krakowskiego ś. Anny z roku szkolnego 1842/1843 w Amfiteatrze Nowodworskim od dnia 17 do 31 lipca 1843 roku od godziny 3 do 7 mej odbywać się majacych na które Prorektor i zgromadzenie Professorów zapraszaja, 1843, Kraków.

Protokół z posiedzenia nadzwyczajnego odbytego w dniu 20.02.1885 r. o godzinie 4 po południu w Sali Arcybractwa Miłosierdzia i Banku Pobożnego przy ulicy Siennej. W: Szósty Tom Protokołu Obrad Rady Ogólnej T.D. od dnia 16 września 1860 rozpoczęty, sygn. TD 8, rękop.

Protokół z posiedzenia nadzwyczajnego Rady Ogólnej w dniu 17.05.1885. W: Szósty Tom Protokołu Obrad Rady Ogólnej T.D. od dnia 16 września 1860 rozpoczęty, sygn. TD 8, rękop. 
Protokół z posiedzenia R.O.T.D. w Krakowie spisany dnia 6.10.1913. W: Protokót z posiedzeń Rady Ogólnej Towarzystwa Dobroczynności począwszy od Stycznia 1909, sygn. TD 319, rękop.

Protokół z posiedzenia Rady Ogólnej zwyczajnego w dniu 4.04.1886. W: Szósty Tom Protokołu Obrad Rady Ogólnej T.D. od dnia 16 września 1860 rozpoczęty, sygn. TD 8, rękop.

Protokół z posiedzenia zwyczajnego Rady Ogólnej Krakowskiego Towarzystwa Dobroczynności w dniu 18.06.1882 r. W: Szósty Tom Protokołu Obrad Rady Ogólnej T.D. od dnia 16 września 1860 rozpoczęty, sygn. TD 8, rękop.

Protokół z posiedzenia zwyczajnego Rady Ogólnej Krakowskiego Towarzystwa Dobroczynności w dniu 5.02.1882. W: Szósty Tom Protokołu Obrad Rady Ogólnej T.D. od dnia 16 września 1860 rozpoczęty, sygn. TD 8, rękop.

Protokół z posiedzenia zwyczajnego Rady Ogólnej Krakowskiego Towarzystwa Dobroczynności w dniu 22.04.1883. W: Szósty Tom Protokołu Obrad Rady Ogólnej T.D. od dnia 16 września 1860 rozpoczęty, sygn. TD 8, rękop.

Protokół z posiedzenia zwyczajnego Rady Ogólnej Krakowskiego Towarzystwa Dobroczynności w dniu 23.12.1883. W: Szósty Tom Protokołu Obrad Rady Ogólnej T.D. od dnia 16 września 1860 rozpoczęty, sygn. TD 8, rękop.

Protokół z posiedzenia zwyczajnego Rady Ogólnej w dniu 12.06.1892. W: Szósty Tom Protokołu Obrad Rady Ogólnej T.D. od dnia 16 września 1860 rozpoczęty, sygn. TD 8, rękop.

Protokół z posiedzenia zwyczajnego Rady Ogólnej w dniu 5.07.1888. W: Szósty Tom Protokołu Obrad Rady Ogólnej T.D. od dnia 16 września 1860 rozpoczęty, sygn. TD 8, rękop.

Protokół z posiedzenia zwyczajnego Rady Ogólnej w dniu 5.05.1889. W: Szósty Tom Protokołu Obrad Rady Ogólnej T.D. od dnia 16 września 1860 rozpoczęty, sygn. TD 8, rękop.

Protokół z posiedzenia zwyczajnego Rady Ogólnej w dniu 7.02.1892. W: Szósty Tom Protokołu Obrad Rady Ogólnej T.D. od dnia 16 września 1860 rozpoczęty, sygn. TD 8, rękop.

Protokół z posiedzenia zwyczajnego Rady Ogólnej w dniu 8.06.1890. W: Szósty Tom Protokołu Obrad Rady Ogólnej T.D. od dnia 16 września 1860 rozpoczęty, sygn. TD 8, rękop.

Protokół Zgromadzenia Ogólnego Członków Krakowskiego Towarzystwa Dobroczynności w d. 9-tym grudnia 1886 r. w celu wybrania nowej Rady Ogólnej Towarzystwa dobroczynności na okres lat 6-ciu poczynając od d. 9 grudnia 1886 r. do d. 9 grudnia 1892 r. W: Szósty Tom Protokołu Obrad Rady Ogólnej T.D. od dnia 16 września 1860 rozpoczęty, sygn. TD 8, rękop. 
Protokół Zgromadzenia Ogólnego Członków Krakowskiego Towarzystwa Dobroczynności w dniu 9 grudnia 1889 r. w celu wyborów uzupełniających Rady Ogólnej Towarzystwa Dobroczynności na następny okres lat 3 poczynając od d. 9 grudnia 1889 do d. 9 grudnia 1892 stosownie do \$14 Statutu Towarzystwa Dobroczynności. W: Ósmy Tom Protokołu Obrad Rady Ogólnej Towarzystwa Dobroczynności w Krakowie rozpoczęty dnia 4 lipca 1875 do 4 września 1892, sygn. 8, rękop.

Protokół Zgromadzenia Ogólnego Członków Krakowskiego Towarzystwa Dobroczynności w dniu 9.12.1892 r. w celu wyborów Rady Ogólnej Towarzystwa Dobroczynności na następny okres lat 3 poczynając od d. 9 grudnia 1892 r. do d. 9 grudnia 1895 r. stosownie do $\$ 14$ statutu Towarzystwa Dobroczynności. W: Protokoły posiedzeń Towarzystwa Dobroczynności w Krakowie od 1892 do 1908, sygn. 9, rękop.

Przeniosło M., 2008, 2010, Dobroczynność i pomoc społeczna na ziemiach polskich w XIX, XX i na początku XXI wieku, t. 1, 2. Kielce, Kieleckie Towarzystwo Naukowe.

Puszka A., 2013, Działalność opiekuńczo-wychowawcza Zakonu Sióstr Miłosierdzia Wincentego A Paulo w Lublinie w XIX i XX wieku. Lublin, Wydawnictwo Naukowe KUL.

Rocznik Krakowskiego Towarzystwa Dobroczynności z roku 1912, 1913, Kraków. Rocznik Krakowskiego Towarzystwa Dobroczynności z 1877, 1878, Kraków. Rocznik Krakowskiego Towarzystwa Dobroczynności z 1912, 1913, Kraków. Rocznik Krakowskiego Towarzystwa Dobroczynności z roku 1889, 1890, Kraków. Rocznik Krakowskiego Towarzystwa Dobroczynności z roku 1907, 1908, Kraków. Rocznik Towarzystwa Dobroczynności Miasta Krakowa z roku 1874, 1875, Kraków. Rocznik Towarzystwa Dobroczynności Wolnego Miasta Krakowa z roku 1838, 1839, Kraków.

Rocznik Towarzystwa Dobroczynności za rok 1886, 1887, Kraków.

Sesja dnia 15.06.1845. W: Czwarty Protokół Posiedzeń Rady Ogólnej Towarzystwa

Dobroczynności w Krakowie od roku 1844, sygn. 4, rękop.

Sprawozdanie Komisji Szkolnej, 1890, W: Rocznik Krakowskiego Towarzystwa Dobroczynności za rok 1889. Kraków.

Statut Krakowskiego Towarzystwa Dobroczynności w Krakowie z 1874 roku, 1874, Kraków.

Statut Krakowskiego Towarzystwa Dobroczynności w Krakowie z 1839 roku, 1839, Kraków.

Statut Towarzystwa Dobroczynności w Krakowie z 1885, 1885, Kraków.

Statut Towarzystwa Dobroczynności w Krakowie, 1901, Kraków, Biblioteka Jagiellońska Dział Rękopisów, sygn. 9716 III. 
Surdacki M., 2002, Losy dzieci porzuconych w społeczeństwie europejskim do XX wieku. W: Dziecko w rodzinie i społeczeństwie. Dzieje nowożytne, K. Jakubiak, W. Jamrożek (red.), t. 2. Bydgoszcz, Wydawnictwo Akademii Bydgoskiej im. Kazimierza Wielkiego.

Wiadomości o czynnościach Wileńskiego Towarzystwa Dobroczynności od czasu jego utworzenia do dnia 1 stycznia 1819 r. przez Sekretarza Towarzystwa Ignacego Jundziłła ułożona, 1819, Wilno.

\title{
TEACHERS OF ORPHANS IN THE CRACOW CHARITABLE ASSOCIATION SOCIETY IN THE YEARS 1817-1912
}

\begin{abstract}
The aim of the article was to show the work of teachers in the daily school and trade school of the Cracow Charity Association in the years 1817-1912. Orphans residing in the Association were given the opportunity to acquire basic knowledge and basic skills that could help them find employment after leaving the place. The School Commission, established in 1874, supported the teachers and controlled their work. In 1912, the school was closed and the orphans attended city schools in Cracow. The teacher's task was to organize and help children learn and exercise, as well as to provide childcare together with the Sisters of Mercy.
\end{abstract}

Keywords: Cracow Charity Association, Galicia, care, orphans, charity 